\title{
Microbial Biomass in Batch and Continuous System
}

\author{
Onofre Monge Amaya, María Teresa Certucha Barragán \\ and Francisco Javier Almendariz Tapia
}

Additional information is available at the end of the chapter

http://dx.doi.org/10.5772/55303

\section{Introduction}

Microorganism is a microscopic organism, commonly used term to describe a cell or more, including viruses [1]. This definition includes all prokaryotes, as the eukaryotic unicellular: protozoa, algae and fungi. Bacteria are an extremely diverse group of organisms with extensive variation of morphological, ecological and physiological, which due to their diversity, are regularly found in heterogeneous communities [2].

The microorganisms are widely used in the biological treatment of waste solids and liquids [3]. Importantly, the microorganisms used in biological treatments as a partnership a community or consortium [2].

Nowadays there is a current increasingly important in the sense of using microorganisms, especially bacteria, algae and fungi, for decontamination and to help recovery from natural environments and for treating municipal or industrial effluents. It is estimated that the best microorganisms for the removal of toxins present in a place, are initially isolated in their own area where they have been naturally selected, although in a second genetic manipulation of these can significantly strengthen the capacity of microorganisms culture collections and isolates from the different environments of interest. This is supported by the observation that microorganisms capable of living in a polluted environment, and thus perform vital functions, in cellular metabolism have highly effective devices for decontamination. To know the details of these mechanisms could be exploited to purify the water, such as using bacteria capable of capturing heavy metals on their cell wall [4].

Thus, this rapid advance of science and technological development has allowed decontamination using microorganisms in the water. Using the metabolism of microorganisms has enabled the construction of biological reactors at much lower cost than 
physicochemical, and also the construction of treatment plants mixed system for greater efficiency [5]. Developed countries currently use these biomining processes through the involvement of bacteria such as Acidithiobacillus ferrooxidans.

Some species of Klebsiella and Pseudomonas are capable of degradation of reactive pollutants. It also recognizes the ability of some microorganisms or their enzymes to degrade under certain conditions to cyanide reagent, employed in the leaching of gold and silver recovery [6]. Several studies have shown that the biomass of different species of bacteria, fungi and algae are capable of concentrating metal ions in their structures that are found in aquatic environments [7].

Bioremediation is defined as a natural process, during in which different microorganisms are capable of removing organic and inorganic contaminants in a given environment [8]. In the bioremediation process, there are different objectives to assess; mainly seeks to avoid a long term noxious effects to other organisms as well as natural resources; it seeks to recover the ecological balance that exists in the environment; and finally, it seeks to achieve that the contaminated area, with a subsequent treatment by biological processes, can be reused for recreation or productive purposes [9].

Different types of biological treatment systems are used in the field of environmental engineering. The biochemical reactions leading to the oxidation of organic matter are conducted in reactors that can be classified as aerobic or anaerobic, suspended growth or biofilm, with mechanical or without mechanical mixing, etc. In order to design an appropriate reactor for a given wastewater treatment system, both the microbial kinetics of substrate removal and the fundamental properties of different reactors have to be understood [10].

The use of microorganisms as tools of decontamination is fairly recent. The biggest advances in the field were made after the oil spill of the Exxon Valdez on the coast of Prince William, in Alaska (1990). Since this ecological disaster lot of oil left in the water, sought alternative ways of dealing with pollution.

The scientists who developed the first successful experiences of bioremediation of oil a large scale in Alaska, were based on the premise that all natural ecosystems have organisms capable of metabolizing toxic compounds and xenobiotics, although these are often found in proportions less than $1 \%$ microbial community. This premise was fulfilled in Alaska and in almost all cases studied later [5].

Several studies have shown that the biomass of different species of bacteria, fungi and algae are capable of concentrating metal ions in their structures that are found in aquatic environments [7]. Bacteria as the genus Pseudomonas of mining environments have been identified that are resistant to heavy metals such as cadmium $(\mathrm{Cd})$, copper $(\mathrm{Cu})$ and lead $(\mathrm{Pb})$ [11]. Some species of marine microalgae, Staphylococcus saprophyticus and fungi have been reported the biosorption of cadmium, chromium, lead and copper from wastewater [7, $12,13]$. 
In other studies it is known that microbial strains are able to bioremediate contaminated soils with different metals and organic compounds. It is known that Escherichia coli is able to bioaccumulate cadmium concentrations of $5 \mathrm{mg} / \mathrm{L}$ as well as copper and zinc which are taken from the culture medium by a process in which occurs a binding peptides secreted by the bacteria [14]. Other studies reported bacterial consortia isolated from mining effluents that adsorbed copper [15], as well as anaerobic consortia that in continuous system showed high percentages of copper and iron removal [16, 17].

It is well-known that the use of the water drainage basins are the primary sources for anthropogenic unloads; it represents a risk for the human health, particularly the pollution caused by the high concentrations of some heavy metals, such as, zinc $(\mathrm{Zn})$, nickel $(\mathrm{Ni})$, chromium $(\mathrm{Cr})$, lead $(\mathrm{Pb})$ and copper $(\mathrm{Cu})[18,19,20]$. Those metals go through the aquatic environment principally by direct loads of industrial sources, soils and sediments and are distributed in the water, biota, being the mining industry one of the most important source $[21,22,23]$. An example of contamination by heavy metals in water and sediment, it is the San Pedro River basin, one of the most important rivers of the north of Sonora, Mexico. This river has been severely contaminated by the wastewater discharges with high concentration of copper generated during the mining activity of the region. In addition, wastewaters discharges untreated raw sewage coming from the city of Cananea, Sonora [24]; also contribute with the pollution of this source of water. Considering the importance and impact of this problem on the community of Cananea city, different kinds of researches had been developing. In reports the sampling stations in the San Pedro River and the propagation and isolation of the bacteria and the copper biosorption in an aerobic bioreactor. However, it is necessary to make more studies that allow suggesting other alternatives for the treatment of acid mine drainages (AMD), and consequently, reducing the concentration of the heavy metals in the San Pedro River, until acceptable levels according to Mexican regulations (NOM-001])[15).

\section{Anaerobic and aerobic process}

\subsection{Anaerobic processes}

Opposite to the aerobic are anaerobic processes, which are performed in the absence of oxygen by groups of heterotrophic bacteria, which in a process of liquefaction/gasification in two stages, becomes a $90 \%$ organic matter present at first in intermediate (partially finished products stabilized that include organic acids and alcohols) and then to methane and gaseous carbon dioxide:

$$
\begin{gathered}
\text { organic mater } \stackrel{\text { acid forming bacteria }}{\longrightarrow} \text { intermediaries }+\mathrm{CO}_{2}+\mathrm{H}_{2} \mathrm{~S}+\mathrm{H}_{2} \mathrm{O} \\
\text { organic acids } \stackrel{\text { methane forming bacteria }}{\longrightarrow} \mathrm{CH}_{4}+\mathrm{CO}_{2}
\end{gathered}
$$

The process is applied universally in hot anaerobic digesters, where in the primary and biological sludge is maintained for about 30 days at $35{ }^{\circ} \mathrm{C}$ to reduce its volume (about $30 \%$ ) 
and their ability to putrefaction, there by simplifies the removal of sludge. The advantage of this type of digestion is that generates energy in the form of methane and the production of sludge is only $10 \%[5,25]$.

\subsection{Anaerobic treatment}

Anaerobic treatment processes require the presence of a diverse closely dependent group of bacteria to bring about the complete conversion of complex mixtures of substrates to methane gas. It is puzzling that single species of bacteria have not evolved to convert at least simple substrates such as carbohydrates, amino acids, or fatty acids all the way to methane [26].

Conventional phase and high-rate two-phase anaerobic digestion processes have frequently been employed in order to treat both soluble and solid types of domestic and industrial wastes. The most significant outcome of anaerobic digestion processes is that they generate energy in the form of biogas namely, methane and hydrogen. Therefore, due to current imperative environmental issues such as global warming, ozone depletion, and formation of acid rain, substitution of renewable energy sources produced from biomass, such as methane and hydrogen, produced through anaerobic digestion processes will definitely affect the demand and consumption of fossil-fuel derived energy [27].

The anaerobic treatment is a biological process widely used in treating wastewater. When these have a high organic load, presents itself as the only alternative would be an expensive aerobic treatment, due to the oxygen supply. The anaerobic treatment is characterized by the production of "biogas" consisting mainly of methane $(60-80 \%)$ and carbon dioxide (40-20\%) and capable of being used as fuel for generating thermal energy and / or electric. Furthermore, only a small fraction of COD treated (5-10\%) is used to form new bacteria, compared to $50-70 \%$ of an aerobic process. However, the slow anaerobic process requires working with high residence times, so it is necessary to design reactors or digesters with a high concentration of microorganisms [28, 29]. Actually is a complex process involving several groups of bacteria, both strictly anaerobic and facultative, which, through a series of stages and in the absence of oxygen, flows mainly in the formation of methane and carbon dioxide. Each stage of the process, described below, is carried out by different groups of bacteria, which must be in perfect balanced. Figure 1 shows a schematic representation of the main conversion processes in anaerobic digestion, suggested by Gujer [30].

(1) Hydrolysis. In this process complex particulate matter is converted into dissolved compounds with a lower molecular weight. The process requires the mediation of exoenzymes that are excreted by fermentative bacteria. Proteins are degraded via (poly) peptides to amino acids, carbohydrates are transformed into soluble sugars (mono and disaccharides) and lipids are converted to long chain fatty acids and glycerine. In practice, the hydrolysis rate can be limiting for the overall rate of anaerobic digestion. In particular the conversion rate of lipids becomes very low below $18^{\circ} \mathrm{C}$. 
(2) Acidogenesis. Dissolved compounds, generated in the hydrolysing step, are taken up in the cells of fermentative bacteria and after acidogenesis excreted as simple organic compounds like volatile fatty acids (VFA), alcohols and mineral compounds like $\mathrm{CO}_{2}, \mathrm{H}_{2}$, $\mathrm{NH}_{3}, \mathrm{H}_{2} \mathrm{~S}$, etc. Acidogenic fermentation is carried out by a diverse group of bacteria, most of which are obligate anaerobe. However, some are facultative and can also metabolize organic matter via the oxidative pathway. This is important in anaerobic wastewater treatment, since dissolved oxygen (DO) otherwise might become toxic for obligate anaerobic organisms, such as methanogens [31].

(3) Acetogenesis. The products of acidogenesis are converted into the final precursors for methane generation: acetate, hydrogen and carbon dioxide. As indicated in Figure 1, a fraction of approximately $70 \%$ of the COD originally present in the influent is converted into acetic acid and the remainder of the electron donor capacity is concentrated in the formed hydrogen. Naturally the generation of highly reduced material like hydrogen must be accompanied by production of oxidized material like $\mathrm{CO}_{2}$.

(4) Methanogenesis. Methanogenesis may be the rate liminting step in the overall digestion process, especially at high temperatures $\left(>18^{\circ} \mathrm{C}\right)$ and when the organic material in the influent is mainly soluble and little hydrolysis is required. Methane is produced from acetate or from the reduction of carbon dioxide by hydrogen using acetotrophic and hydrogenotrophic bacteria, respectively:

$$
\begin{gathered}
\text { Acetotrophic methanogenesis: } \mathrm{CH}_{3} \mathrm{COOH} \rightarrow \mathrm{CH}_{4}+\mathrm{CO}_{2} \\
\text { Hydrogenotrophic methanogenesis: } 4 \mathrm{H}_{2}+\mathrm{CO}_{2} \rightarrow \mathrm{CH}_{4}+2 \mathrm{H}_{2} \mathrm{O}
\end{gathered}
$$

Different from aerobic treatment where the bacterial mass was modeled as a single bacterial suspension, anaerobic treatment of complex wastewaters, with particulate matter in the influent, is only feasible by the action of a consortium of the four mentioned groups of bacteria that each have their own kinetics and yield coefficients. The bacteria that produce methane from hydrogen and carbon dioxide grow faster than those utilizing acetate that the acetotrophic methanogens usually are rate limiting for the transformation of acidified wastewaters to biogas [32].

The different groups of bacteria involved in the conversion of influent organic matter all exert anabolic and catabolic activity. Hence, parallel to the release of the different fermentation products, new biomass is formed associated with the four conversion processes described above. For convenience, the first three processes often are lumped together and denominated acid fermentation, while the fourth step is referred to as methanogenic fermentation.

The removal of organic matter-COD during the acid fermentation is limited to the release of hydrogen only $30 \%$ of the organic matter is converted into methane via the hydrogenotrophic pathway. Hence, a necessary condition for efficient organic matter removal in an anaerobic treatment system is that a sufficient mass of acetotrophic methanogens develops. 


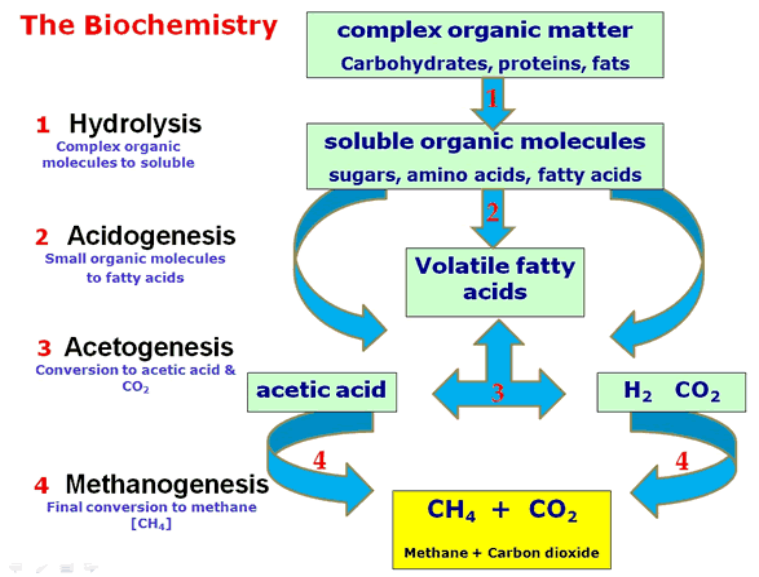

Figure 1. Schematic representation of the main conversion processes in anaerobic digestion

Acid fermentation tends to cause a decrease in the $\mathrm{pH}$ because of the production of VFA and other intermediates that dissociate and produce protons. As methanogenesis will only develop well at a neutral $\mathrm{pH}$ values, instability may arise, if for some reason the rate of acid removal by methane production falls behind the acid production rate: the net production of acid will tend to cause a decrease in $\mathrm{pH}$, and thus may reduce the methanogenic activity further. In practice, this so called "souring" of the anaerobic reactor contents is the most common cause for operational failure of anaerobic treatment systems. The danger of souring can be avoided, by maintaining the proper balance between acid and methanogenic fermentation which in fact means that both the methanogenic digestion capacity and buffer capacity of the system should be sufficiently high $[29,33]$.

\subsection{Chemical oxygen demand (COD)}

Natural organic detritus and organic waste from wastewater treatment plants, failing septic systems, and agricultural and urban runoff, acts as a food source for water-borne bacteria. Bacteria decompose these organic materials using dissolved oxygen. The determination of Chemical Oxygen Demand (COD) is widely used in municipal and industrial laboratories to measure the overall level of organic contamination in wastewater. The contamination level is determined by measuring the equivalent amount of oxygen required to oxidize organic matter in the sample.

In the COD method, the water sample is oxidized by digesting in a sealed reaction tube with sulphuric acid and potassium dichromate in the presence of a silver sulphate catalyst. The amount of dichromate reduced is proportional to the COD. A reagent blank is prepared for each batch of tubes in order to compensate for the oxygen demand of the reagent itself.

Over the range of the test a series of colors from yellow through green to blue are produced. The color is indicative of the chemical oxygen demand and is measured using a photometer. The results are expressed as milligrams of oxygen consumed per liter of sample [34]. 


\section{Test Procedure}

i. Mixed reagent. Potassium dichromate solution. To a $1000 \mathrm{~mL}$ volumetric flask, add $42.256 \pm 0.001 \mathrm{~g}$ of potassium dichromate (previously dried for one hour at $140-150{ }^{\circ} \mathrm{C}$ ). To the flask, add approximately $500 \mathrm{~mL}$ of water and mix the contents to dissolve. Then add $33.3 \mathrm{~g}$ de $\mathrm{HgSO}_{4}$ to the potassium solution. Add in an ice bath slowly $167 \mathrm{~mL}$ pure $\mathrm{H}_{2} \mathrm{SO}_{4}$. When the mixture has cooled, stir the mixture until the solid dissolves and dilute to one liter.

ii. Silver sulphate in sulphuric acid (10 g). To a glass bottle, add $10.0 \pm 0.1 \mathrm{~g}$ of silver sulphate and $1000 \pm 10 \mathrm{~mL}$ of sulphuric acid and stopper. To obtain a satisfactory solution, swirl the initial mixture and allow it to stand overnight. Swirl the contents again until all the silver sulphate dissolves. This solution may be stored in the dark at room temperature for up to an indefinite period.

iii. Pipette $2.0 \mathrm{~mL}$ sample into cuvette with $2.0 \mathrm{~mL}$ of the mixed reagent solution and 1.0 $\mathrm{mL}$ of the silver sulphate in sulphuric acid solution. Invert cuvettes carefully.

iv. Heating reactor for determination of COD for about 30 minutes.

v. Heat cuvettes for $2 \mathrm{~h}$ at $150{ }^{\circ} \mathrm{C}$.

vi. read cuvettes in the spectrophotometer at $620 \mathrm{~nm}$.

\subsection{Technique to determine alkalinity}

Typical control strategy in methanogenic anaerobic reactors is to maintain a relatively low concentration of volatile fatty acids (VFA) and a $\mathrm{pH}$ range of $6.6<\mathrm{pH}<7.4$. Normally in such reactors the carbonate system forms the main weak-acid system responsible for maintaining the $\mathrm{pH}$ around neutrality, while the VFA systems (acetic, propionic, and butyric acids) are the major cause for $\mathrm{pH}$ decline. Under stable operating conditions, the $\mathrm{H}_{2}$ and acetic acid formed by acidogenic and acetogenic bacterial activity are utilized immediately by the methanogens and converted to methane. Consequently, the VFA concentration is typically very low, carbonate alkalinity is not consumed and the $\mathrm{pH}$ is stable. Conversely, under overload conditions or in the presence of toxins or inhibitory substances, the activity of the methanogenic and acetogenic populations is reduced causing an accumulation of VFA which in turn increases the total acidity in the water, reducing $\mathrm{pH}$. The extent of the $\mathrm{pH}$ drop depends on the $\mathrm{H}_{2} \mathrm{CO}_{3}$ alkalinity concentration. In medium and well-buffered waters (typically the case in anaerobic digestion), high concentrations of VFA would have to form in order to cause a detectable $\mathrm{pH}$ drop, by which time reactor failure would have occurred. Therefore, $\mathrm{pH}$ measurement cannot form the sole control means, and direct measurement of either (or both) VFA or $\mathrm{H}_{2} \mathrm{CO}_{3}$ alkalinity concentration is necessary.

The most used technique for the determination of alkalinity for the control of the system anaerobic is described below:

$25 \mathrm{~mL}$ of sample are taken and placed on a plate with stirring to a solution titrated with 0.02 $\mathrm{N}$ sulfuric acid, it initial $\mathrm{pH}$ is measured and the acid is added until the $\mathrm{pH}$ changes to 5.75 volume of spent acid, followed by titrating until the $\mathrm{pH}$ changes to 4.3 and the volume of spent acid is taken and is determined the alpha value. 
Alpha $=$ acid vol. (5.75)/ acid vol. (4.3) if this value is greater than 0.55 the bioreactor is acidified and must add a buffer, on the contrary, if it is less, acid must be added [35].

\subsection{Methanogenic activity determination}

The specific methanogenic activity $\left(\mathrm{SMA}=\mathrm{gDQO}-\mathrm{CH}_{4} \cdot \mathrm{gVSS}^{-1} \cdot \mathrm{d}^{-1}\right)$ is defined as the rate of methane production, expressed as COD, regarding biomass expressed as the content of volatile suspended solids (VSS). In anaerobic degradability test measures the rate of degradation of a compound relative to a standard compound that is acetic acid determining [36].

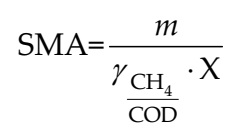

Where: Slope $=\mathrm{m}=\frac{\mathrm{LCH}_{4}}{\mathrm{~d}} ;$ Biomass $=\mathrm{X}[=] \mathrm{gVSS} / \mathrm{L} ;$ Methane conversion $\gamma \frac{\mathrm{CH}_{4}}{\mathrm{COD}}=0.35 \frac{\mathrm{LCH}_{4}}{\mathrm{gCOD}}$

Methanogenic activity and toxicity

Methanogenic activity were performed using the pressure transducer technique, which involves the monitoring of the pressure increase developed insealed vials fed with nongaseous substrates or pressure decrease in vials pressurised with gaseous substrates. Strict anaerobic conditions must be maintained. The same technique can be used to perform the methanogenic toxicity tests. The fifty percent inhibition concentration (IC50) was defined as the methanogenic concentration that caused a $50 \%$ relative activity loss $[35,37]$.

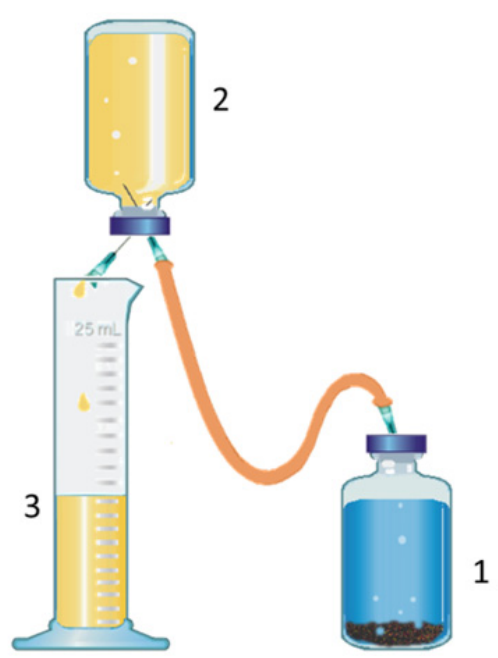

Figure 2. Schematic representation of methane measuring displacement of a solution of $3 \% \mathrm{NaOH}$. 1) serological bottle, 2) serological bottle with $3 \% \mathrm{NaOH} 3$ ) test tube to measure the displaced $\mathrm{NaOH}$ 
The technique is as follows:

1. The sludge is left in mineral medium for 24 hours at $30-35^{\circ} \mathrm{C}$ in order to consume the entire carbon source which may have been brought into water of the plant.

2. Methanogenic activity tests were conducted in $160 \mathrm{~mL}$ in serology bottles with an operating volume of $150 \mathrm{~mL}$. The volume of volatile suspended solids was set at $2 \mathrm{~g} / \mathrm{L}$ and COD concentration used was varied from $0.25,0.5,1,2,3$ y $5 \mathrm{~g} / \mathrm{L}$ using acetate as a carbon source, and staying a relationship of $0.125,0.25,0.5,1,1.5$ y 2.5 gCOD/gVSS respectively.

3. The bottles were sealed with rubber stoppers, and incubated $24 \mathrm{~h}$ at $35^{\circ} \mathrm{C}$.

4. Methane was determined by the displacement volume of a solution of $3 \% \mathrm{NaOH}$ [38].

Figure 2 show a schematic representation of methane measuring.

\subsection{Characterization of the sludge (total suspended solids (TSS), volatile suspend solids (VSS), fixed solids (FS))}

The total solids (TS) contents of sludge are used in the design and process control of wastewater treatment facilities. Total dissolved solids (TDS) are used to evaluate the suitability of water for both domestic supplies and industrial purposes. The total suspended solids (TSS), including the volatile fraction (VSS), are commonly monitored to evaluate the degree of pollution in natural waters and serves as a key process control parameter for wastewater treatment operation.

The measurement of solids is by means of the gravimetric procedure. The various forms of solids are determined by weighing after the appropriate handling procedures.

1. Placing a clean porcelain crucible for $60 \mathrm{~min}$ at $550{ }^{\circ} \mathrm{C}$ in the muffle then is passed to a desiccator to cool and then weighed (noted as weight of the crucible).

2. Add with a blunt pipette $10 \mathrm{~mL}$ of anaerobics sludge. In a warming rack remove all the water possible. Go to the muffle furnace at $100{ }^{\circ} \mathrm{C}$ within $2 \mathrm{~h}$; after this time is cooled and weighed (weight recorded as $100^{\circ} \mathrm{C}$ ).

3. Place the crucible in the muffle at $550{ }^{\circ} \mathrm{C}$ for $1 \mathrm{~h}$ and pass it to the desiccator and record the weight of the crucible (as weight at $550{ }^{\circ} \mathrm{C}$ ).

4. Finally returned to the desiccator. After obtaining the three weights, and proceeded to determine the total solids, volatile and fixed as follows: [35]

$$
\begin{aligned}
& \text { Total suspended solids } \\
& \text { Fixed solids }: \frac{\text { Weight to } 100^{\circ} \mathrm{C}-\text { Weight of the crucible }}{\text { Sample volume }}[=] \frac{g}{\mathrm{~g}} \\
& \quad F S: \frac{\text { Weight to } 550^{\circ} \mathrm{C}-\text { Weight of the crucible }}{\text { Sample volume }}[=] \frac{g}{L}
\end{aligned}
$$

Volatile suspended solids VSS :TSS - FSS[ $[=] \frac{g}{L}$ 


\subsection{Setting sludge volume index (SVI)}

The sludge volume index is defined as 'the volume in $\mathrm{mL}$ occupied by $1 \mathrm{~g}$ of sludge after it has settled for a specified period of time' generally ranging from $20 \mathrm{~min}$ to 1 or $2 \mathrm{hr}$ in a 1 or $2 \mathrm{~L}$ cylinder. One-half hour is most common setting time allow the mixed liquor to settle for $30 \mathrm{~min}$. (larger cylinder is desirable to minimize bridging of sludge floe and war effects). SVI is $50-150 \mathrm{~mL} / \mathrm{mg}$, the sludge settle ability if good.

SVI typically is used to monitor settling characteristics of activated sludge and other biological suspension. Although SVI is not supported theoretically, experience has shown it to be useful in routine process control. The SIV determination consisted of:

1. Place in the imhoff cone of $1000 \mathrm{~mL}, 100 \mathrm{~mL}$ of sludge and diluted to $1000 \mathrm{~mL}$ with phosphate buffer.

2. Was allowed to stand for 45 minutes and then stir the contents with a glass rod.

3. The volume occupied by the mud was measured by sedimentation after 30 minutes.

4. The SIV was calculated by dividing this volume by the present VSS $\mathrm{g}$ in $100 \mathrm{~mL}$ of sludge (Sludge/gVSS) [34].

\subsection{Granule density}

Among all the different types of anaerobic digesters applied at full scale, UASB (Upflow Anaerobic Sludge Blanket) reactors present the best commercial acceptance. The success of these reactors is related to their capacity for biomass accumulation by settling without the need of a carrier. Good settling properties are obtained through the flocculation of the biomass in the form of dense granules with diameters up to several millimetres. Actually, as individual cells and granules have similar densities, the greater settling velocity of the latter is only related to its larger particle size. The study of this phenomenon has lead to the development of several techniques for characterizing the resistance of the granules, their porosity, settling properties, bacterial composition and organization, activity, nature and composition of exopolymers, as well as their size distribution. This last parameter is particularly useful for studying the physico-chemical factors promoting sludge granulation [38].

1. Search about 6 stainless steel screens with an aperture of about 2 to $0.149 \mathrm{~mm}$ for the test.

2. In a vertical stack such that always at the top this larger diameter with respect to the bottom.

3. Take and pass a sample of $25 \mathrm{~mL}$ of sludge by the sieves.

4. Washing the sludge with a buffer and phosphate to make them pass through the screens; separated by size.

5. Retrieve the granules, separately, to be retained in the meshes with a backwash of phosphate buffer solution (Table 1) and then determine VSS, FS and TSS [38]. 


\begin{tabular}{ll}
\hline Compound & g/L \\
\hline $\mathrm{K}_{2} \mathrm{HPO}_{4}$ & 4 \\
$\mathrm{Na}_{2} \mathrm{HPO}_{4} \cdot 7 \mathrm{H}_{2} \mathrm{O}$ & 5.09 \\
$\mathrm{KH}_{2} \mathrm{PO}_{4}$ & 1.08 \\
pH solution 7.5 & \\
\hline
\end{tabular}

Table 1. Phosphate buffer solution

\section{Aerobic processes}

Among the biological processes used for the construction of bioreactors, there are two fundamental types of processes: the aerobic and anaerobic.

Aerobic processes are those that need oxygen. There are strict aerobic processes, which are those that can only work if there is oxygen, and facultative aerobic processes, which are those that can switch to anaerobic, according to the concentration of oxygen available.

In general, the aerobic processes have the following reaction:

$$
\text { organic materia }+\mathrm{O}_{2} \rightarrow \mathrm{CO}_{2}+\mathrm{H}_{2} \mathrm{O}+\text { new cells }
$$

As can be seen in the above reaction, essentially, aerobic metabolism is responsible for catalyzing larger molecules into carbon dioxide, water and new cells. It is noteworthy that the different groups of microorganisms have different metabolisms, and therefore are able to catalyze a wide range of substances, although sometimes other secondary products are obtained in addition to those mentioned.

Aerobic processes are very efficient, operate at a wide range of possible substances to degrade, and in relatively simple cycles are stable; there is rapid conversion of organic pollutants in microbial cells and their operation relatively free of odors [38].

\subsection{Growth of microorganisms}

\subsubsection{Isolation}

Most of classical and clinical microbiology depends on the isolation of a pure culture that consists of only one species. This isolate is then later used for characterization such as species determination or an antibiotic resistance profile. For many applications it is essential to isolate and maintain a pure culture of the organism of interest. The goal is to obtain isolated colonies of the organism of interest. These colonies arise from one single cell and are therefore a clone of that original cell. The original cell is called a colony-forming unit (CFU). To obtain a pure culture, it is crucial to maintain a sterile environmental.

To accomplish the microbiological analysis and isolation of strains, water samples are collected, this should be in sterile plastic containers of $500 \mathrm{~mL}$. Is performed enrichment in nutrient broth, to ensure a favorable conditioning bacteria that may be stressed by 
environmental conditions and ensure better isolation, for which they are placed $10 \mathrm{~mL}$ of sterile nutrient broth sample, duplicate it.

Incubate at $37^{\circ} \mathrm{C}$ for 24 hours and reseed poured plate technique or grooves in the selected specific culture media: nutrient agar for Bacillus sp and Pseudomonas sp; agar EMB (eosin methylene blue) for Enterobacteriaceae; agar M17 for Enterococcus. Also plantings from water samples directly on agar PDA (Potato Dextrose Agar) acidifying the medium with tartaric acid for the isolation of fungi and yeast, and incubated at $22{ }^{\circ} \mathrm{C}$ [38].

\subsection{Macroscopic and microscopic characterization}

All cells contain the same mayor macromolecules in approximately the same proportions which perform essentially to same functions. Cell shape and arrangement are the initial steps for identifying bacteria. Cell grouping is related to the number of division and whether the cells remain together or separate after division. The Gram stain is an important toll for the classification and eventual identification of bacterial species.

The macroscopic characterization of the colonies was determined according to the observation of general appearance: shape, color, size, texture, elevation and range. The microscopic characterization to observe shape, color and size was performed by Gram stain for bacteria, with lactophenol blue stain for fungi and solution saline for yeast [37, 39].

\subsection{Characterization of strains}

\subsubsection{Biochemical characterization and selection of strains}

To grow, microorganisms from the environment should take all the substances required for the synthesis of their cellular materials and power generation. These substances are known nutrients. A culture medium should contain, therefore, all the necessary nutrients in appropriate amounts in the specific requirements of the microorganisms to what has been devised. At selected strains were performed the following biochemical tests, in order to know their identification: catalase production, nitrate reduction, mobility, indole production, the use of citrate as a carbon source, production of urease, methyl red, VogesProskauer, carbohydrate fermentation, starch hydrolysis, gelatin hydrolysis and hydrolysis of esculin $[40,41]$. To determine resistance to low $\mathrm{pH}$, this is changed in the culture media from 3 to 6 . The $\mathrm{pH}$ was measured with a potentiometer, is adjusted with $10 \mathrm{M} \mathrm{NaOH}$ (sodium hydroxide) and $\mathrm{HCl}$ (hydrochloric acid).

\subsection{Growth kinetics}

The relatively large surface area of microorganisms exposed to the environment where they live enables them to take up and assimilate nutrients readily and a to multiply at impressive rates. An important parameter is the specific growth rate, wich is often expressed as the mean doubling time, defined as the time required by the microbial population to douyble its cellular protein content. The doubling time varies widely depending on the microbial species, the nature of the substrate and the degree of adaption to the substrate. 
The growth of a bacterial culture can be determined by measuring the increase of turbidity in the medium as optical density or OD. The most common way to do this is to compare the absorbance of the culture to inoculated medium by shining light with a wavelength of 600 $\mathrm{nm}$ through the culture. The more growth occurs, the more turbid the culture will become and more light will be absorbed. Using optical density gives indirect measurement of bacterial growth. It doesn't tell anything about how many living cells are in the culture. This becomes especially important in stationary phase. Dead cells still absorb light. To determine the actual number of live bacteria the broth is diluted and plated on appropriate media and incubated. In theory, colonies arising on a plate originate from one single bacterium and give therefore an accurate number of the live cells in the culture at that time point.

Procedure:

The kinetics of selected bacterial growth, it is used $10 \mathrm{~mL}$ of $24 \mathrm{~h}$ culture of the strains and inoculated into $60 \mathrm{~mL}$ of nutrient broth, the following conditions: $35{ }^{\circ} \mathrm{C}$ and $100 \mathrm{rpm}$ agitation. Samples were read every 30 minutes in a Spectronic $20 \mathrm{D}^{+}$visible spectrophotometer at $600 \mathrm{~nm}$, substituting readings transmittance $(\% \mathrm{~T})$ in the following equation:

$$
A=2-\log _{10}(\% T)
$$

Where $\mathrm{A}$, is the absorbance.

The different phases of growth kinetics can be observed by plotting the log $(\% \mathrm{~T})$ versus time [1].

\subsection{Biosorption process with bacteria in batch system}

Microbial growth and substrate utilization expressions can be incorporated into mass balances to yield equations that can be used to predict effluent microorganism and substrate concentrations, and thus process efficiency. Continuous flow systems are grouped into two broad categories, suspended-growth and attached-growth processes, depending on whether the process microorganisms are maintained in suspension, or are attached to an inert medium (e.g., rocks, sand, granular activated carbon, or plastic materials). Attached-growth processes are also called fixed-film processes or biofilm processes.

Biosorption has provided an alternative process to the traditional physico-chemical methods, utilizing inexpensive biomass to sequester toxic heavy metals. In the 80 last decades, many researchers have focus on the treatment of wastewater containing heavy metals by the use of living organisms and/or their biomass. Many types of organisms such as bacteria, fungi, yeast and algae or their biomasses, have been used for metal uptake [42].

Biosorption tests batch system are carried out with each strain selected in $500 \mathrm{~mL}$ erlenmeyer flask, add $90 \mathrm{~mL}$ of a solution containing the metal to study, at an initial concentration established and adding $10 \mathrm{~mL}$ culture of $24 \mathrm{~h}$ of each strain, with a biomass concentration of $1 \mathrm{~g} / \mathrm{L}$. Target used $100 \mathrm{~mL}$ of metal solution without bacteria. Samples were 
analyzed in duplicate for each strain. Is used nephelometer of McFarland to estimate the number of cells/mL [40, 42]. The conditions established are: $\mathrm{pH}$ between 4 and 5, if the metal precipitates at neutral $\mathrm{pH}, 37^{\circ} \mathrm{C}$ and $100 \mathrm{rpm}$ agitation [44, 45]. To read the metal concentration is done by atomic absorption spectrophotometry, taking $5 \mathrm{~mL}$ sample every 15 minutes and prepared as described by $[23,46]$ and the concentration is calculated from the calibration curve prepared with standard solution of each metal studied. The detection limits can be $0.02 \mathrm{mg} / \mathrm{L}$, analyzing in duplicate.

\subsection{Affecting parameters}

Within the anaerobic and aerobic environment, various important parameters affect the rates of the different steps of the process, i.e. $\mathrm{pH}$ and alkalinity, temperature, and hydraulic retention times.

Each group of microorganisms has a different optimum $\mathrm{pH}$ range. Methanogenic bacteria are extremely sensitive to $\mathrm{pH}$ with an optimum between 6.5 and $7.2 \mathrm{pH}$, alkalinity and volatile acids/alkalinity ratio. The fermentative microorganisms are somewhat less sensitive and can function in a wider range of $\mathrm{pH}$ between 4.0 and 8.5. at a low $\mathrm{pH}$ the main products are acetic and butyric acid, while at a $\mathrm{pH}$ of 8.0 mainly acetic and propionic acid are produced.

The temperature has an important effect on the physicochemical properties of the components found in the digestion substrate. It also influences the growth rate and metabolism of microorganisms and hence the population dynamics in the anaerobic reactor. Acetotrophic methanogens are one of the most sensitive groups to increasing temperatures. The degradation of propionate and butyrate is also sensitive to temperatures above $70{ }^{\circ} \mathrm{C}$. The temperature has moreover a significant effect on the partial pressure of $\mathrm{H}_{2}$ in digesters, hence influencing the kinetics of the syntrophic metabolism. Thermodynamics show that endergonic reactions (under standard conditions), for instance the breakdown of propionate into acetate, $\mathrm{CO}_{2}, \mathrm{H}_{2}$, would become energetically more favourable at higher temperature, while reactions which are exergonic (e.g. hydrogenotrophic methanogenesis) are less favoured at higher temperatures.

The solids retention time (SRT) is the average time the solids spend in the digester, whereas the hydraulic retention time (HRT) is the average time the liquid sludge is held in the digester. The subsequent steps of the digestion process are directly related to the SRT. A decrease in the SRT decreases the extent of the reactions and viceversa. Each time sludge is withdrawn, a fraction of the bacterial population is removed thus implying that the cell growth must at least compensate the cell removal to ensure steady state and avoid process failure [28].

\subsection{McFarland nephelometer}

The McFarland nephelometer was described in 1907 by J. McFarland as an instrument for estimating the number of bacteria in suspensions used for calculating the bacterial opsonic index and for vaccine preparation. 
Another important factor is known that cells per milliliter are taken at a given time, and a known way is through the \% of transmittance and that can be determined by the technique of McFarland nephelometer, which is described below.

McFarland Nephelometer Standards

a. Set up 10 test tubes or vials of equal size and quality: Use new hoses washed and completely dry.

b. Prepare $\mathrm{H}_{2} \mathrm{SO}_{4} 1 \%$ chemically pure.

c. Prepare an aqueous solution of barium chloride, $1 \%$ chemically pure.

d. Add to the tubes the designated amounts of the two solutions as shown in Table 2 for a total of $10 \mathrm{~mL} /$ tube.

e. Close the tubes or vials. The suspension of barium sulphate corresponding to an approximately homogeneous precipitate of density of the cells per milliliter in the standard variable, as shown in the Table 2.

f. In the Figure 3(a) shows the \% of transmittance against the number. From the tube which can be removed if there is not a spectrophotometer to read the transmittance, and in Figure 3(b) shows the number of cells that are depending on number.

\begin{tabular}{|c|c|c|c|c|c|c|c|c|c|c|}
\hline Tube's Number & $\mathbf{1}$ & $\mathbf{2}$ & $\mathbf{3}$ & $\mathbf{4}$ & $\mathbf{5}$ & $\mathbf{6}$ & $\mathbf{7}$ & $\mathbf{8}$ & $\mathbf{9}$ & $\mathbf{1 0}$ \\
\hline Barium chloride $(\mathrm{mL})$ & 0.1 & 0.2 & 0.3 & 0.4 & 0.5 & 0.6 & 0.7 & 0.8 & 0.9 & 1 \\
\hline Sulfuric Acid $(\mathrm{mL})$ & 9.9 & 9.8 & 9.7 & 9.6 & 9.5 & 9.4 & 9.3 & 9.2 & 9.1 & 9 \\
\hline $\begin{array}{c}\text { Aprox. Cell density } \\
\left(\mathrm{X} 10^{8} / \mathrm{mL}\right)\end{array}$ & 3 & 6 & 9 & 12 & 15 & 18 & 21 & 24 & 27 & 30 \\
\hline
\end{tabular}

Table 2. McFarland Nephelometer Standards

Population density is monitored by taking readings of \% of transmittance, which compared to the McFarland nephelometer; transmittance readings should be less than $10 \%$ in order to maintain the population density. This technique is used to know the time and turbidity of most practical way to achieve the desired amount of biomass for biosorption experiments batch system and continuous [39].

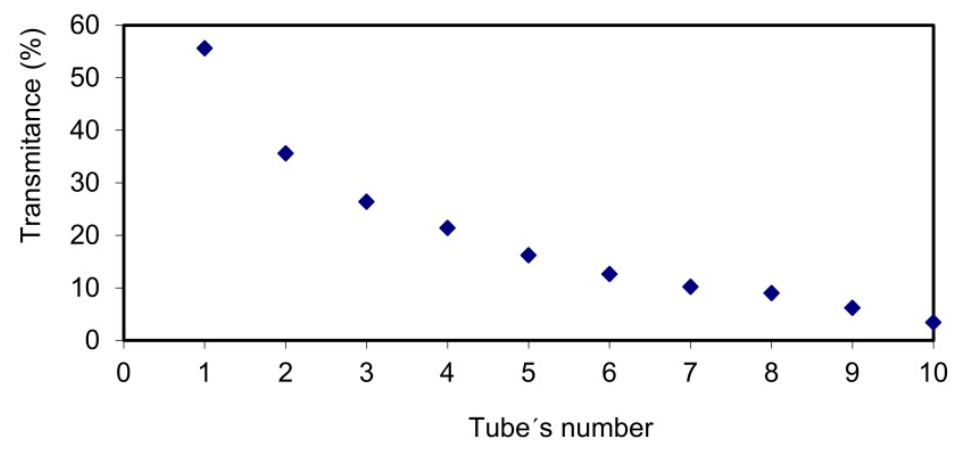

(a) 


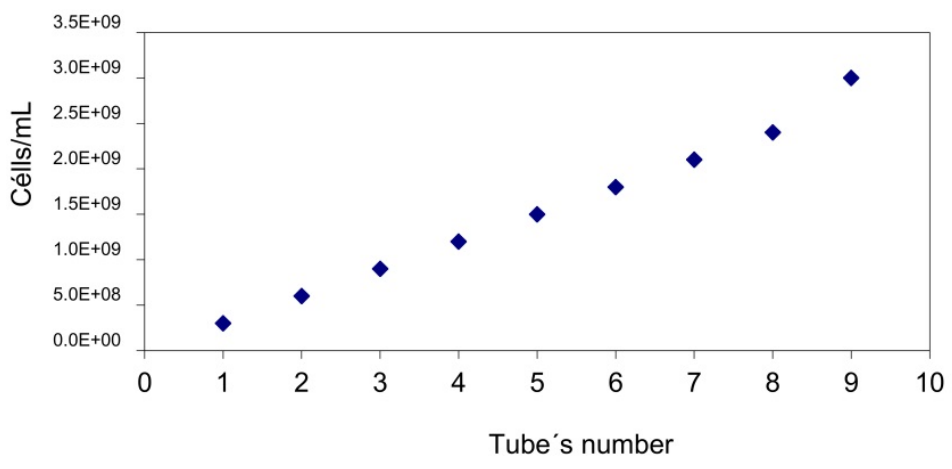

Figure 3. Standard curves of nephelometer with transmittance (\%) and cell density

\section{System in batch and continuous culture}

The construction of bioreactors is based on a simple principle: make the pollutants are converted into the substrate (food) of microorganisms, and that these, while feeding and increases its population, decontaminated water. For the construction of a bioreactor is necessary to know the type of microorganisms with which they are going to work and as well as the growth curve characteristic of them [5].

The key factor of a bioreactor is to maintain microorganisms in the growth stage most of the time as possible, i.e. keep the microbial population to its maximum level, to optimize the efficiency of the degradation processes. This is achieved by controlling the environmental conditions (temperature, $\mathrm{pH}$, aeration and nutrient availability) and the flows in and out, so never lack food and do not reach the death phase or endogenous $[2,5]$.

The teams that are made homogeneous reactions can be of three general types: discontinuous (batch), continuous flow steady and unsteady flow semicontinuous.

Batch reactors are simple to operate and industrially used when small amounts are to treat substance. Continuous reactors are ideal for industrial purposes be treated when large quantities of substance and can achieve good control of product quality. Semicontinuous reactors are more flexible systems, but more difficult to analyze and operate than previous; in them the reaction rate can be controlled with a good strategy at the dosage of the reactants [48].

In a perfect batch reactor there is no entry or exit of reactant. It is further assumed that the reactor is well stirred, i.e. that the composition is the same at all points of the reactor for a given time instant. Since the input and output are zero the material balance is:

$$
\left(\begin{array}{l}
\text { Disappearance of } \\
\text { reactant by } \\
\text { chemical reaction }
\end{array}\right)=-\left(\begin{array}{l}
\text { Reactant } \\
\text { accumulation in the } \\
\text { control volume }
\end{array}\right)
$$


All points have the same composition; the volume control to perform the balance is the entire reactor. Evaluating the terms:

$$
\mathrm{rAV}=-\frac{\mathrm{dNA}}{\mathrm{dt}}
$$

And given that: $N_{A}=N_{A o}\left(1-X_{A}\right)$ results:

$$
\mathrm{rAV}=\mathrm{NA} 0 \frac{\mathrm{dX} A}{\mathrm{dt}}
$$

Integrating gives the equation for the design for the batch reactor:

$$
\mathrm{t}=\mathrm{NAo} \int_{0}^{X_{\mathrm{A}}} \frac{\mathrm{dXA}}{\mathrm{rAV}_{\mathrm{A}}}
$$

If the reaction volume remains constant may be expressed in function of the concentration of reagent $C_{A}=N_{A} / V$

$$
\mathrm{t}=\mathrm{CAo}_{\mathrm{o}} \int_{\mathrm{A}}^{\mathrm{X}_{\mathrm{A}}} \frac{\mathrm{dX} \mathrm{XA}_{\mathrm{A}}}{\mathrm{rA}_{\mathrm{A}}}=-\int_{\mathrm{CAO}_{\mathrm{A}}}^{\mathrm{C}_{\mathrm{A}}} \frac{\mathrm{dCA}}{\mathrm{rA}_{\mathrm{A}}}
$$

This intermittent or batch reactor is characterized by the variation in the reaction's degree and the properties of the reaction mixture with the lapse of time [49]

A batch reactor has no inflow or outflow reagents of the reaction products while being performed. In almost every batch reactors, the longer that a reactant in the reactor, most of it becomes product to reach equilibrium is exhausted or the reagent [50].

The reactor of the continuous flow type, in which the degree of reaction can vary with respect to the position in the reactor, but not a function of time. Therefore, one of the classifications of the reactors is based on the operation method [49].

Normally, the conversion increases with time that the reagents remain in the reactor. In the case of continuous flow systems, this time usually increases with increasing reactor volume; therefore, the conversion $\mathrm{X}$ is a function of reactor volume $\mathrm{V}$ [50].

The tubular reactor plug flow (RTFP) is characterized in that the flow is directed, without any element of the exceeding or being mixed with any other element located before or after that, i.e. no mixing in the flow direction (axial direction). As a result, all fluid elements have the same residence time within the reactor [48].

As fluid composition varies along the reactor, material balance must be performed in a differential volume element transverse to the direction of flow.

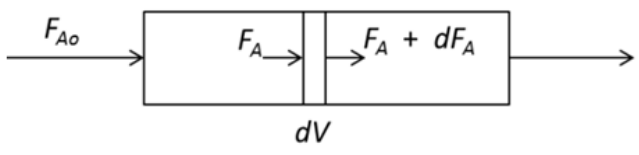




$$
\begin{gathered}
\text { Inlet }=\text { Outlet }+ \text { Disappearance of reaction } \\
\qquad F_{A}=F_{A}+d F_{A}+r_{A} d V
\end{gathered}
$$

Given that $d F_{A}=d\left[F_{A o}\left(1-X_{A}\right)\right]=-F_{A o} d X_{A}$ by substitution is

$$
F_{A o} d X_{A}=r_{A} d V
$$

That integrated is

$$
\int_{0}^{\mathrm{V}} \frac{\mathrm{dV}}{\mathrm{FAo}_{\mathrm{A}}}=\int_{0}^{\mathrm{XAf}} \frac{\mathrm{dXA}}{\mathrm{rA}}
$$

Or:

$$
\tau=\frac{\mathrm{V}}{\mathrm{V}_{\mathrm{o}}}=\mathrm{CAoo}_{\mathrm{O}}^{\mathrm{X}_{\mathrm{Af}}} \frac{\mathrm{dXA}}{\mathrm{rA}}
$$

In some cases it is convenient to divide the output current of a plug flow reactor by returning part of it to the reactor inlet.

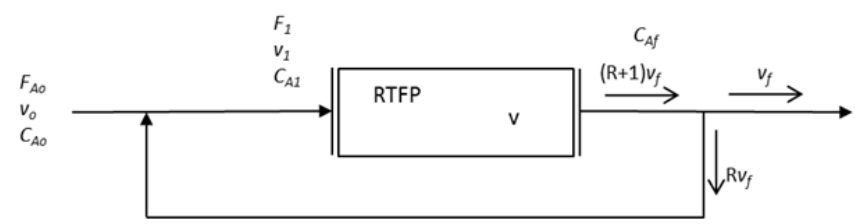

The recirculation ratio is defined:

$$
R=\frac{\text { flow which is recycled }}{\text { flow out }}
$$

Raising the design equation for the reactor (within the recycle loop) without expansion

$$
\frac{\mathrm{V}}{\mathrm{V} 1}=-\int_{\mathrm{CA} 1}^{\mathrm{CAA}} \frac{\mathrm{dCA}}{\mathrm{rA}}
$$

If its considers that there is no expansion or contraction in the reactor, raising the junction of the inlet and the recirculation $V_{1}=(R+1) V_{o}$ and furthermore $C_{A 1}=\left(C_{A o}+C_{A f}\right) /(R+1)$, therefore the equation of reactor design is:

$$
\tau=\frac{\mathrm{V}}{\mathrm{V}_{\mathrm{o}}}=-(\mathrm{R}+1) \int_{\left(\frac{\mathrm{CAO}+\mathrm{RCAf}}{\mathrm{R}+1}\right)}^{\mathrm{CAA}}
$$

Another classification relates to the shape. If a laboratory vessel is equipped with a stirrer efficient, composition and temperature of the reaction mass will tend to be equal in all areas of the reactor. A container in which there is uniformity of properties is called a stirred tank reactor (or well mixed) or STR [48]. 


\subsection{Anaerobic continuous studies}

Generally, the design rules of biological reactors are all based on high removal efficiency of degradable organic matter. Consequently, if the substrate composition and strength of a wastewater are known, a basic design of a high-rate anaerobic system can be established. According to [52], the main design criteria of UASB reactors are, among others: applicable organic load, upflow velocity, three-phase separator, and influent distribution system.

The UASB reactors are generally designed based on the organic volumetric load (OVL) $\left(\mathrm{kgCOD} / \mathrm{m}^{3}\right.$-day) that is defined as follows:

$$
O V L=Q S o / V
$$

where $Q$ : influent flow rate $\left(\mathrm{m}^{3} /\right.$ day $)$, So: influent $\mathrm{COO}\left(\mathrm{kgCOD} / \mathrm{m}^{3}\right)$, and $V$ : volume of reactor $\left(\mathrm{m}^{3}\right)$, From Equation (21) the volume of the reactor, $V$, can be obtained:

$$
V=Q S_{0} / O V L
$$

For most industrial wastewaters, the OVL (based on degradable COD) is the critical factor for the reactor volume. Its value depends on the quantity and quality of the granular sludge; the nature, type, and concentration of the pollutants; the temperature; the required treatment efficiency and the desired safety regarding peak loads [16, 53].

\subsection{Studies of biosorption of heavy metals with aerobic bacteria using biomass support in batch system}

For studies of biosorption of heavy metals using aerobic bacteria and a support for the biomass, using $500 \mathrm{~mL}$ Erlenmeyer flasks, which are placed $5 \mathrm{~g}$ of the support for the immobilization of selected biomass, $90 \mathrm{~mL}$ of a solution containing the metal study established at an initial concentration, $10 \mathrm{ml}$ of biomass with a density of $1 \mathrm{~g} / \mathrm{L}$ and as target, $100 \mathrm{~mL}$ of metal with $5 \mathrm{~g}$ of support material. The flasks were plugged with a cotton swab having aeration, then is placed in an incubator with shaking at $100 \mathrm{rpm}$ and temperature established for mesophilic bacteria to $45^{\circ} \mathrm{C}$. Samples are taken at set times to analyze the concentration of metals by atomic absorption. The conditions are the same for the studies using only bacteria without carrier material. All experiments were performed in duplicate and the efficiency of biosorption (E) is calculated using the equation:

$$
E=\left(\frac{C_{o}-C_{f}}{C_{o}}\right) * 100
$$

Where: $C_{o}$ y $C_{f}$ initial and final amounts of the metal $(\mathrm{mg} / \mathrm{L})$.

\subsection{Studies of heavy metal biosorption in a continuous system with aerobic biomass using biomass support}

Biosorption is a rapid phenomenon of passive metal sequestration by the non-growing biomass. To carry out the studies of metal biosorption in a continuous system is conditioned 
first a reactor column, which has side ports for sampling. The reactor is packed with carrier material of biomass with a particle size between 1 and $6 \mathrm{~mm}$, to avoid clogging. Both mineral medium such as air are fed through the bottom of the reactor to promote the growth of bacteria and the $\mathrm{pH}$ is controlled if the metal to be studied could precipitate at neutral $\mathrm{pH}$. The mineral medium is inoculated with $10 \%$ biomass that develop in this medium for the time given the growth kinetics and the reactor is kept in recirculation until the development of biomass $(1 \mathrm{~g} / \mathrm{L})$ and that adheres to support material. Biomass concentration was estimated by measuring the percent of transmittance to an optical density at $600 \mathrm{~nm}$ $\left(\right.$ Spectronic $20 \mathrm{D}^{+}$) and for the amount of biomass produced in cells/mL was determined using the Table 2 of McFarland nephelometer, described above.

When produced in the reactor is $1 \mathrm{~g} / \mathrm{L}$ of biomass and this is immobilized in the zeolite, are set constant conditions of operation of the reactor as: air flow 10 times the feed flow of the contaminated medium, hydraulic retention time (HRT) of a day and ambient temperature of $30{ }^{\circ} \mathrm{C}$. The tests are performed to set conditions of initial concentrations of metals and $\mathrm{pH}$ set, and takes days to the input samples at different heights of the reactor and output to meet the metal concentration, biomass is recycled to make more time contact between the bacteria and the metal being studied. It can be perform a second and third experimental run at different initial concentrations of feeding and at the same $\mathrm{pH}$, maintaining the feed stream and recirculation same. Other studies may be changing the $\mathrm{pH}$, keeping other conditions constant.

In the experimental runs carried out is analyzed for $\mathrm{pH}$, metal concentration by atomic absorption and to determine the concentration of cells $/ \mathrm{mL}$ of biomass, measures the percentage of transmittance in the spectronic $20 \mathrm{D}^{+}$and compared by the technique of Nephelometer of Mc Farland. The support used is analyzed by the technique of sludge digestion, are performed analyzes of biomass produced per day and chemical oxygen demand (COD). At the end of the experiments are performed technical analyses of the medium used X-ray Diffraction (XRD), scanning electron microscopy (SEM) and Energy Dispersive Spectroscopy X-ray (EDS) at different column heights to see if deposited on the support certain amount of heavy metals or all was absorbed by the biomass.

\subsection{Support the immobilization of biomass}

Immobilization of cells as biocatalysts is almost as common as enzyme immobilization. Immobilization is the restrict ion of cell mobility within a defined space. Immobilized cell cultures have the following potential advantages over suspension cultures.

- Immobilization provides high cell concentrations.

- Immobilization provides cell reuse and eliminates the costly processes of cell recovery and cell recycle.

- Immobilization eliminates cell washout problems at high dilution rates.

- The combination of high cell concentrations and high flow rates (no washout restrictions) allows high volumetric productivities. 
- Immobilization may also provide favorable microenvironmental conditions (i.e., cellcell contact, nutrient-product gradients, $\mathrm{pH}$ gradients) for cells, resulting in better performance of the biocatalyst» (e.g., higher product yields and rates).

- In some cases, immobilization improves genetic stability.

- For some cells, protection against shear damage is important.

The major limitation on immobilization is that the product of interest should be excreted by the cells. A further complication is that immobilization often leads to systems for which diffusional limitations are important. In such cases the control of microenvironmental conditions is difficult, owing to the resulting heterogeneity in the system. With living cells, growth and gas evolution present significant problems in some systems and can lead to significant mechanical disruption of the immobilizing matrix.

The primary advantage of immobilized cells over immobilized enzymes is that immobilized cells can perform multistep, cofactor-requiring, biosynthetic reactions that are not practical using purified enzyme preparations.

Adsorption of cells on inert support surfaces has been widely used for cell immobilization. The major advantage of immobilization by adsorption is direct contact between nutrient and support materials. High cell loadings can be obtained using microporous support materials. However, porous support materials may cause intraparticle pore diffusion limitations at high cell densities, as is also the case with polymer-entrapped cell systems. Also, the control of microenvironmental conditions is a problem with porous support materials. A ratio of pore to cell diameter of 4 to 5 is recommended for the immobilization of cells onto the inner surface of porous support particles. At small pore sizes. Accessibility of the nutrient into inner surfaces of pores may be the limiting factor, whereas at large pore sizes the specific surface area may be the limiting factor. Therefore, there may be an optimal pore size, resulting in the maximum rate of bioconversion.

Adsorption capacity and strength of binding are the two major factors that affect the selection of a suitable support material. Adsorption capacity varies between $2 \mathrm{mg} / \mathrm{g}$ (porous silica) and $250 \mathrm{mg} / \mathrm{g}$ (wood chips). Porous glass carriers provide adsorption capacities (10 $10^{8}$ to $10^{9}$ cells/g) that are less than or comparable to those of gel-entrapped cell concentrations $\left(10^{9}\right.$ to $10^{11}$ cells $/ \mathrm{mL}$ ). The binding forces between the cell and support surfaces may vary, depending on the surface properties of the support material and the type of cells. Electrostatic forces are dominant when positively charged support surfaces (ion exchange resins, gelatin) are used. Cells also adhere on negatively charged surfaces by covalent binding or $\mathrm{H}$ bonding. The adsorption of cells on neutral polymer support surfaces may be mediated by chemical bonding, such as covalent bonding, $\mathrm{H}$ bonds, or van der Waals forces. Some specific chelating agents may be used to develop stronger cell-surface interact ions. Among the support materials used for cell adsorption are porous glass, porous silica, alumina, ceramics, gelatin, chitosan, activated carbon, wood chips, polypropylene ionexchange resins (DEAE-Sephadex, CMC-), and Sepharose [54].

Various reactor configurations can be used for immobilized cell systems. Since the support matrices used for cell immobilization are often mechanically fragile, bioreactors 
with low hydrodynamic shear, such as packed-column, fluidized-bed, or airlift reactors, are preferred. Mechanically agitated fermenters can be used for some immobilized-cell systems if the support matrix is strong and durable. Any of these reactors can usually be operated in a perfusion mode by passing nutrient solution through a column of immobilized cells [54].

Since the design of reactors for the removal of heavy metals from liquid effluent must consider optimum contact between these and the biomass, it has been considered the use of different types of support for the immobilization of the biomass with the aim of achieving greater efficiency in removing heavy metals. This achieves prevent biosorbent is removed from the reactor in the output current and at the same time is obtained a greater mechanical stability thereby reducing the shear stresses that could damage the structure of the microorganism which affects removal efficiency heavy metals [53].

Living biomass immobilized, must first take the form of biofilm on supports prepared from a variety of inert materials. One of the materials that have been studied as biomass support is activated carbon by porosity and high surface area, besides being an abundant product is obtained as a byproduct of the production of oil from coconut, olive and processing sugarcane [53]. Other materials have been used as biomass support such as silica, polyacrylamide gel and polyurethane include agar, cellulose, alginates, polyacrylamides, the silica gel, sand, textile fibers, calcium alginate, polysulfone, glutaraldehyde and other organic compounds, and have been used for removing heavy metals [55,56].

There are other materials that could be used for biomass carriers; such as the natural zeolites are known important industrial applications due to its high affinity for water and that the cavities only allow passage of molecules of a certain size. Have been used as additives in animal feed, such as soil improvers in agriculture due to increased nitrogen retention and soil moisture, and as catalysts in industrial processes of refining, petrochemicals and fine chemicals [57].

\subsubsection{Activated charcoal}

The name of activated charcoal is applied to a series of artificially prepared porous carbons to exhibit a high degree of porosity and a high inner surface. These characteristics are responsible for their adsorptive properties, which are used widely in many applications in gas phase and liquid phase. Chemically it is composed of carbon, oxygen, hydrogen and ash. The activated carbon adsorbent is a very versatile, because the size and distribution of pores in the carbonaceous structure can be controlled to meet the current and future technology. The pore sizes ranging from smaller called micropores $(2.0 \mathrm{~nm})$ until the mesopores $(2-50 \mathrm{~nm})$ and macropore $(<50 \mathrm{~nm})$. It should be borne in mind that most adsorption occurs in the micropores (greater than $90 \%$ of the surface area) the mesopores and macropores are extremely important because in the activated charcoal are those which facilitate access of the species will adsorb to the interior of the particle and of the micropores [58]. 
One of the materials that have been studied as biomass support is activated charcoal. Its high porosity and high surface area activated charcoal make it an ideal material to be carried out the process of adsorption of heavy metals. Another reason why activated charcoal is used for the adsorption is its low cost, since it is an abundant product is obtained as a byproduct of the production of oil from coconut, olive and processing of sugar cane [55].

\subsubsection{Glutaraldehyde}

Microbial cells can be immobilized by cross-linking between cells, using bi or multifunctional reagents as glutaraldehyde or toluene di isocyanate.

Glutaraldehyde is a colorless liquid with a pungent odor used to sterilize medical and dental equipment is also used in water treatment industry and as a chemical preservative. However, it is toxic and can cause severe eye irritation, nose, throat and lungs, along with headaches, drowsiness and vomiting. Glutaraldehyde monomer can polymerize by aldol condensation, giving poliglutaraldehído alpha, beta unsaturated reaction typically occurs at alkaline $\mathrm{pH}$ [59].

\subsubsection{Silica}

The mechanism involved is based on the formation of covalent bonds between the inorganic support (silica) and cells in the presence of crosslinking agents. A said joint is needed for the modification of the support surface. The reaction requires the introduction of reactive organic groups on the silica surface for the attachment of cells to the support. As coupling agent generally used aminopropyl triethoxy silane; this organic functional group condenses with hydroxyl groups of the silica and the group as a result becomes available for covalent bond formation on the surface. Covalent bonds can also be established by treating the silica surface with glutaraldehyde or isocyanate.

The advantage of this method is that the support can be generated without the limitations on physical and chemical conditions imposed by the biocatalyst, which can be optimized by the characteristics of mechanical stability, porosity, strength of the support, etc.

When you want to form covalent bonds between the substrate and cells, the problem is how to promote adhesion of cells to relatively large surface without damaging its stability and resistance to washing. The support may have pores of greater diameter than the cell to allow the latter to penetrate the internal surfaces. Porous supports are used which are embedded by immersion in cell suspensions [60].

Another important matrix being used for immobilization for metal removal is silica. Silicaimmobilized preparations offer advantage in terms of reusability and stability. The silica immobilized product is mechanically strong and exhibits excellent flow characteristics [68]. A silica immobilized algal preparation AlgaSORBR (Bio-Recovery Systems, Inc., Las Cruces, NM 80003, USA) which is being used commercially retains approximately $90 \%$ of the original metal uptake efficiency even after prolonged use (> 18 months) [57]. 


\subsubsection{Polyacrylamide gel}

Polyacrylamide gels are formed by polymerization of acrylamide by the action of a crosslinked agent, is chemically inert, uniform properties, able to be prepared quickly and reproducibly. Thus, in addition, transparent gels with mechanical stability, water insoluble, relatively non-ionic and allow good visualization of the bands for a long time. Also has the advantage that by varying the concentration of polymers can be modified in a controlled manner the pore size, there sometimes is used in diagnosis least because of their neurotoxocidad [59].

Whole cell immobilization within a polyacrylamide gel also provides a useful laboratory scale system and has been used to biosorb and recover a number of heavy metal(s). Good results have been obtained in the case of polyacrylamide immobilized cells of Citrobacter where a very high removal of uranium, cadmium and lead was observed from solutions supplemented with glycerol $-2 \mathrm{PO}_{4}$. Rhizopus arrhizus biomass immobilized on polyacrylamide gel was effective in almost completely removing $\mathrm{Cu}^{2+} \mathrm{Co}^{2+}$ and $\mathrm{Cd}^{2+}$ from synthetic metal solution $[26,55]$.

\subsubsection{Polyurethane}

Inert materials such as polyurethane, impregnated with a suitable culture medium provided a homogeneous aerobic condition in the fermenter and impurities do not contribute to the final product. An additional advantage of using inert supports is the easy recovery of the product of interest, ease of performing balances because all nutrient concentrations in the middle of production are known, so one can study the effect of a given component of medium [60].

Recent studies have shown the superiority of polyurethane and polysulfone as immobilization support in comparison to polyacrylamide and alginate matrices. It has been reported a novel polyurathane gel bead fabrication technique for immobilizing Pseudomonas aeruginosa CSU. Preliminary studies conducted by them revealed that the P. aeruginosa CSU biomass immobilized within the polyurethane gel beads were effective in the removal of hexavalent uranium from low concentration acidic waters. Other authors have been immobilized phormidium laminosum on polysulfone and epoxy resins. They were successful in reusing the polysulfone immobilized biomass for ten consecutive biosorption/desorption cycles without apparent loss of efficiency after reconditioning it with $0.1 \mathrm{M} \mathrm{NaOH}$. Immobilization of Citrobacter biomass in polysulfone matrix increased its metal loading capacity for lead, cadmium and zinc metals [57].

\subsubsection{Alginate}

There are many studies on the composition of alginate and its advantages to cell immobilization. Because the chemical composition of this polymer and as a consequence that the same reactions can be obtained in reaction, alginate gels are recommended for cells sensitive to environmental conditions. Recent studies of the diffusional characteristics of the 
immobilized system, have improved our understanding of the environment surrounding the immobilized cells, optimize protocols and improve the stability of alginate gels [60].

One of the matrices that have been used in metal recovery by both viable and non-viable cells is the entrapment in the matrix of insoluble Ca-alginate. Fluidized beds of Caentrapped cells of Chlorella vulgaris and Spirulina platensis were successfully used to recover gold from a simulated gold-bearing process solution containing $\mathrm{AuCl}_{4}, \mathrm{CuCl}_{2}, \mathrm{FeCl}_{2}$ and $\mathrm{ZnCl}_{2}$. The Ca-alginate immobilized cells of Chlorella salina also showed greater binding of cobalt, zinc and manganese than the free cells. Rhizopus arrhizus entrapped on alginate beads was successfully used for the removal of uranium over multiple biosorption and desorption cycles. Accumulation was also dependent on cell density in alginate beads with greater uptake of cobalt at the highest cell densities [57].

\subsubsection{Natural zeolite}

Zeolites are crystalline aluminosilicates, three-dimensional, microporous, based on framework structure with a rigid anion, with well-defined channels and cavities. These cavities contain exchangeable metal cations $\left(\mathrm{Na}^{+}, \mathrm{K}^{+}\right.$, etc.) And can also retain removable and replaceable guest molecules (water in natural zeolites). To date about 40 have been characterized structures of natural zeolites and have developed more than 130 synthetic structures. The most important natural zeolites are analcime, chabazite, clinoptilolite, erionite, ferrierite, heulandite, laumontite, and phillipsite mordonita [58].

Zeolites are composed of aluminum, silicon, sodium, hydrogen and oxygen. The crystal structure is based on the three network addresses with $\mathrm{SiO}_{4}$ tetrahedral shaped with four oxygens shared with adjacent tetrahedra. The physical properties unique aspects provide for a wide variety of practical applications. Figure 4 shows the basic structure of the zeolite tetrahedral [63].
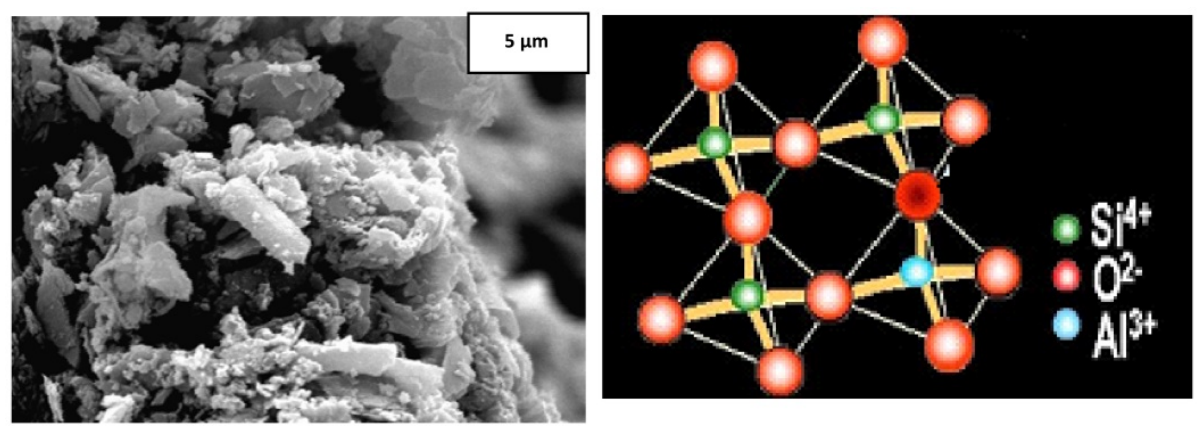

Figure 4. Basic tetrahedral structure of the zeolites.

The physical properties of the zeolite are that they possess features bright, hardness and wear resistance. Applications of natural zeolites make use of one or more of its chemical properties, usually including adsorption, ion exchange and catalysis. These properties are a function of the crystal structure of each species, cationic structure and composition [63]. 
Clinoptilolite is from the zeolite minerals are best known for its uses and applications. It is a natural zeolite formed from volcanic ash in lakes and marine waters millions of years ago. Clinoptilolite, is the most studied and is considered more useful, since it is known as an adsorbent of certain toxic gases such as hydrogen sulfide and sulfur dioxide. In fact few countries that have had deposits in operation, including: Japan, Italy, USA, Russia, Hungary, Bulgaria, Cuba, Yugoslavia and Mexico [39]. Recognizes the capacity of the zeolites natural adsorb heavy metals and other contaminants from water. In certain cases, it requires a pretreatment of the zeolite to modify or improve its adsorption properties [62].

\section{Conclusion}

This chapter has provided the results of research of aerobic and anaerobic biomass in the batch and continuous system using a support for the biomass: silica, polyacrylamide gel, polyurethane, calcium alginate, glutaraldehyde, charcoal and zeolites. The use of support for the biomass increases the development of the microorganisms. Also describes the affecting parameters: time, $\mathrm{pH}$, temperature, HRT, toxicity and stirring speed. Also in this chapter describe the techniques for determination of parameters for anaerobic such as, chemical oxygen demand (COD), alkalinity, methane production, total solids (TSS), volatile solids (VSS), volatile fatty acids (VFA) concentrations, and for the aerobics, the biomass concentration using \% of transmittance, McFarland nephelometer, isolation, macroscopic and microscopic characterization, growth kinetics, in batch and continuous system.

\section{Author details}

Onofre Monge Amaya, María Teresa Certucha Barragán

and Francisco Javier Almendariz Tapia

University of Sonora, Department of Chemistry and Metallurgy. Hermosillo, Sonora. México

\section{Acknowledgement}

This work was made possible through support provided by the University of Sonora, through the Department of Chemical Engineering and Metallurgy, and Engineering Division. The authors would like to thank: The National Council for Science and Technology (CONACyT), well as students Gisel Figueroa, Gonzalo Figueroa, Guadalupe López, Karla Hernandez, Hiram Bañuelos, Carlos Jaramillo, Luis Carlos Platt, Axel Valenzuela, Glenda Duarte.

\section{References}

[1] Madigan M.T., Martinko J. M., Parker J. (2004) Brock Biología de los microorganismos, ED. Prentice Hall. 647 p.

[2] Eweis J. B., Ergas S. J., Chang D. P., Schroeder E. D., Tejero M. I., Amieva del Val J.J. (1999) Principios de biorrecuperación (Bioremediation). Primera Edición. Mac Graw Hall Interamericana. 4, 12, 21, 94. 
[3] Atlas. M.R. y Bartha R. (2002) Ecología microbiana y microbiología ambiental. 4a Ed. Pearson educación. Madrid, España. pp. 3-24.

[4] Steciow M. (2005) Microbiología Ambiental http:www.cricyt.edu.ar/enciclopedia/términos/Biorremed. Htm

[5] Fontúrbel R. F. e Ibáñez N.C. (2004). Empleo del Metabolismo Microbiano para la Descontaminación de Aguas. Biología y Ciencias de la Salud. No. 17.

[6] Saigí F. y López A. (2004) Las ciencias de la vida y la biotecnología en la nueva sociedad del conocimiento. La base de la nueva economía. http://www.uoc.edu/dt/esp/saigi1104.pdf. Agosto-2008.

[7] Basso, M.C., Cerella, E.G.,Cukierman, A.L (2002) Empleo de Algas Marinas para la Biosorción de Metales Pesados de Aguas Contaminadas. Avances en Energías Renovables y Medio Ambiente. Argentina. 6:1

[8] Cotoras T. D. (2003) Bacterias para descontaminar aguas residuales de la minería y la industria. Facultad de Ciencias Químicas y Farmacéuticas. Universidad de Chile. Induambiente 13(14): 27-29. http://www.estrucplan.com.ar/Secciones/Noticias/Noticia.asp. Abril 2012

[9] Mijares M. A. P. (2003) Aislamiento y Caracterización de Bacterias con Capacidad para Inmovilizar Cadmio. Tesis Licenciatura. Biología con área en Biotecnología. Universidad de las Américas, Puebla. Capítulo dos.

[10] Cervantes Carlos (2006) Las Relaciones de las Bacterias y los Metales. Carisma de la Ciencia 3: 1-4.

[11] Rivas B.G.A., Gutierréz, S., Merino F. (2004) Bioremoción de Metales Pesados en Solución por Pseudomonas fluorescens M1A-45 Aisladas de Ambientes Minero. Segunda Semana de Ciencia y Tecnología.

[12] Acosta I., Moctezuma-Zárate M. G., Cárdenas J. F. y Gutiérrez C. (2007) Bioadsorción de Cadmio (II) en Solución Acuosa por Biomasa Fúngicas. Información Tecnológica. 18:1: 9-14.

[13] Ilhan S., Nourbakhsh M.N., Kilicarslan S., Ozdag H. (2004) Removal of Chromium, Lead and Copper Ions From Industrial Waste Waters by Sthaphlococcus saprophyticus Turkish Electronic Journal of Biotechnology. 2, 50-57.

[14] Lasat M. M. (2002) Phytoextraction of toxic metals: A review of biological mechanisms. J. Environ. Qual. 31,109-120.

[15] Monge, O., Valenzuela, J., Acedo, E., Certucha, M., \& Almendáriz, J. (2008) Biosorción de cobre en sistema por lote y continuo con bacterias aerobias inmovilizadas en zeolita natural (clinoptilolita). Rev. Int. Contam. Ambient. 24 (3) 107-115.

[16] Certucha-Barragán M.T, Acedo-Félix E, Monge-Amaya O, Valenzuela-García J.L, Almendariz-TapiaF.J, Leal-Cruz A.L (2009) Copper Bioaccumulation in an Upflow Anaerobic Sludge Blanket (UASB) Reactor Chemical Speciation and Bioavailability. 21:3: 161-164.

[17] Certucha-Barragán M. T, Acedo-Félix E, Almendariz-Tapia F. J, Pérez-Moreno R, Monge-Amaya, Valenzuela Garcia J. L, and O. Monge-Amaya (2011) Iron Influence on Copper Biosorption Using Anaerobic Sludge and its Microstructural Characterization, Mineral Processing \& Extractive Metall. Rev., 32: 1 - 8. 
[18] Topalián M.L., Castané P.M, Rovedatti, M.G. and Salibián A. (1999) Principal Component Analysis of Dissolved Heavy Metals in Water of the Reconquista River (Buenos Aires, Argentina). Bull. Environ. Contam. Toxicol 63: 484-490.

[19] Karri S, Sierra-Alvarez, R and Field J.A. (2006) Toxicity of Copper to Acetoclastic and Hydrogenotrophic Activities of Metanogens and Sulfate Reducers in Anaerobic Sluge. Chemosphere, 62: $121-127$.

[20] Upadhyay, A.K., Gupta, K.K., Sircar, J.K., Deb, M.K. and Mundhara, G.L. (2006) Heavy Metals in Freshly Deposited Sediments of the Rivers Subernarenkha, India: an Example of Lithogenic and Anthtopogenic Effects Environ. Geol., 50:397-403.

[21] Elder, F.J. (1988) Metal Biogeochemistry in Surface-Water Systems A Review of Principles and Concepts, U. S. Geologycal Survey Circular 1013, U.S.A

[22] Alloway, B.J. and Ayres, D.C. (1993) Chemical Principles of Environmental Pollution. Blackie Academic \& Professional. New York, USA. pp. 291.

[23] Gomez-Alvarez et al., 2007 Gómez-Álvarez, A., Valenzuela-García, J. L., AguayoSalinas, S., Meza-Figueroa, D., Ramirez-Hernández, J., Ochoa-Ortega, G. (2007) Chemical partitioning of sediment contamination by heavy metals in the San Pedro River, Sonora, Mexico. Chemical Speciation and Bioavailability. 19, 25-36.

[24] Gómez-Álvarez, A. (2001). Evaluación de la calidad física y química del agua y sedimento del Río San Pedro, Sonora, México, Durante el Periodo 1997-1999. Tesis de Maestría en Ciencias de la Ingeniería. Universidad de Sonora

[25] Henry J. G. y Heinke W.G. (1999) Ingeniería Ambiental. Ed Prentice Hall. pp. 195, 196, 431.

[26] Speece R.E. (1996) Amaerobic Biotchnology.Archae Press.pp.24-63

[27] Burak Demirel, Paul Scher ,Orhan Yenigun, and Turgut Onay (2010) Production of Methane and Hydrogen from Biomass through Conventional and High-Rate Anaerobic Digestion Processes Critical Reviews in Environmental Science and Technology. 40:116-146.

[28] Lise Appels , Jan Baeyens , Jan Degre've , Raf Dewil (2008) Principles and Potential of the Anaerobic Digestion of Waste-Activated Sludge Progress in Energy and Combustion Science. 34: 755-781.

[29] A.c. van Haanadel 2006 Advanced Biological Treatment Processes for Industrial Wastewaters Principles and Applications.In: Francisco 1.Cervantes, Spyros G. Pavlostathis and Adrianus C. van Haandel: in IWA.pp. 67-70.

[30] Gujer, W. and Zehnder, AJ. (1983) Conversion Processes in Anaerobic Digestion Wat.Sci.Techn. 15,127.

[31] Chiu-Yue LIinm and Chin-Chao Chen (1999) Effect of Heavy Metals on the Methanogenic UASB Granule Wat. Res. 33, 2, pp. 409-416.

[32] Henzen, M. and Harremoes, P. (1983) Anaerobic Treatment of Waste Water in Fixed Film Reactors - a Literature Review Wat.Sci. Techn. 15, 1.

[33] Sandoval C, Carreño M. De, Castillo E F, Vergara M. (2007) Sludge Anaerobic Microbiologic Characterization Used in the Organic Fraction of Urban Solid Waste Treatment Scientia et Technica Año XIII, 35:509-514. 
[34] APHA. Standard Methods for the Examination of Water and Wastewater (1995) Washington DC, USA: American Public Health Association/American Water Works Association/Water Environment Federation.

[35] Bouvier J.C., Steyer J.P. and Delgenes J.P. (2002) On-line titrimetric sensor for the control of VFA and/or alkalinity in anaerobic digestion processes treating industrial vinasses, VII Latin American Workshop and Symposium on Anaerobic Digestion, Merida, Mexico, October 23-25/2001, 65-68.

[36] Almendariz F. J. (2005) Tratamiento de Sosas Gastadas en un Reactor de Lecho Expandido de Lodo Granular Anaerobio Tesis Doctoral. Universidad Autónoma Metropolitana. México, D.F.

[37] Alves M., Cavaleiro A.J., Ferreira E.C., Amaral A.L, Mota M., da Motta M., Vivier H. and Pons M-N. (2000) Characterisation by image analysis of anaerobic sludge under shock conditions. Water Science and Technology Vol 41 No IWA Publishing 12. 207214.

[38] Laguna A., Ouattara A., González R. O., Barón O., Fama G., El Mamouni R., Guiot S., Monroy O. y Macarie H. (1999) A Simple and Low Cost Technique for Determining the Granulometry of Upflow Anaerobic Sludge Blanket Reactor Wat. Sci. Technol 40 (8): 18.

[39] Onofre Monge, Leobardo Valenzuela y Evelia Acedo (2010) Biosorción de Cobre con Bacterias Aerobias Inmovilizadas en Zeolita. Aislamiento, Caracterización, Selección de Microorganismos y Cinética de Biosorción. Lambert Academic Publishing.

[40] Aquiahuatl R. M.A. y Pérez Ch. M.L. (2004) Manual de prácticas del laboratorio de microbiología general. UAM. México. Pp. 37-49.

[41] Koneman E. W., Allen S., Janda W., Schrenberger P., Winn W. (1999) Diagnóstico microbiológico. Médica Panamericana. México. pp. 1-349; 1258-1357.

[42] Mac Faddin J. F. (2003) Pruebas bioquímicas para la identificación de bacterias de importancia clínica. Médica Panamericana. Pp. 54 -421.

[43] Abuzer Çelekli a, Mehmet Yavuzatmacab, Hüseyin Bozkurtc (2010). An ecofriendly process: predictive modelling of copper adsorption from aqueous solution on Spirulina platensis. Journal of Hazardous Materials. Vol.173, 123-129.

[44] Monge A. O. (2003) Biorrestauración de suelos contaminados por cianuro, utilizando Bacillus sp. Tesis de Maestría en Ciencias de la Ingeniería. Universidad de Sonora.

[45] Duarte S. D. (1997). Evaluación de la capacidad de biosorción de Ni(II) por Thiobacillus Ferrooxidans. Tesis de Licenciatura en Ingeniería Química. Universidad de Sonora.

[46] Oliveira M. J. (2003). Estudio de la biosorción de cobre por perlas de alginate de calcio. Tesis de Licenciatura. Universidad Nacional Mayor de San Marcos. Perú.

[47] Agemian H. y Chau A. S. Y. (1975) An atomic absorption method for the determination of 20 elements in lake sediments after acid digestion. Analytica Chemica Acta 80:61-66.

[48] Borzacconi L. y López I. (2003) Cinética de ingeniería de reacciones. Notas de curso. Facultad de Ingeniería. http://www.fing.edu.uy/iq/reactores/cursos/reactores1.pdf consulta: Abril-2012.

[49] Smith J. M. (1991) Ingeniería de la Cinética Química. ED. Continental. México D. F. pp. 369-377. 
[50] Fogler, H. S., Escalona G. R. L. y Ramírez S. J. F. (2001) Elementos de ingeniería de las reacciones químicas. Pearson Educación. México. pp. 8-11; 34-39.

[51] Jawed, M. and Tare, V (1999) Microbial Composition Assessment of Anaerobic Biomass Through Methanogenic Activity Tests Water S.A 25. 3: 345 - 350.

[52] Lettinga, G., van Velsen, A.F.M., Hobma, S.W., De Zeeuw, W. y Klapwijk, A. (1980) Use of the Upflow Sludge Blanket (UASB) Reactor Concept for Biological Wastewater Treatment, Especially for Anaerobic Treatment. Biotechnol. Bioeng .22: 699-734.

[53] Certucha-Barragán M. T, Duarte-Rodríguez G. R, Acedo-Félix E, Almendariz-Tapia F. J, Monge-Amaya, Valenzuela Garcia J. L, Leal-Cruz A. (2010) Estudio de la Biosorción de Cobre Utilizando Lodo Anaerobio Acidogénico. Rev. Int. Contam. Ambient. 2: 26-36.

[54] Shuler, M. L. and Kargi, F. (2002) Bioprocess Engineering: Basic Concepts, 2nd edition,Prentice-Hall. Inc .

[55] Reyes E. D., Cerino C. F. y Suárez H. M. A. (2006) Remoción de metales pesados con carbón activado como soporte de biomasa. Ingenierías. IX, 31.59-64.

[56] Cañizares- Villanueva, R. O. (2000) Biosorción de metales pesados mediante el uso de biomasa microbiana. Revista Latinoamericana de Microbiología. 42:131-143.

[57] Gupta R., Prerna Ahuja, Seema Khan, R. K. Saxena and Mohapatra H. (2000) Microbial biosorbents: Meeting challenges of heavy metal pollution in aqueous solutions. CURRENT SCIENCE, 78, 8, 967-973.

[58] Leyva Ramos R., Medellín C. N. A., Guerrero C. R.M., Berber M. M.S., Aragón P. A. y Jacobo A. A. (2005) Intercambio iónico de plata (I) en solución acuosa sobre clinoptilolita. Rev. Int. Contam. Ambient. 21 (4) 193-200.

[59] Rodríguez, H. (2001). Estudio de la contaminación por metales pesados en la Cuenca de Llobregat. Tesis Doctoral. Barcelona.

[60] Vega B. (2008) Inmovilización de células. 1ำ Curso Iberoamericano de Biocatálisis Aplicada a Química Verde. Facultad de Química. Universidad Nacional de Quilmes. Argentina.

[61] Krause, U., Thomson-carter, F.M. and Pennington, T.H. (1996) Molecular Epidemiology of Escherichia coli O157:H7 by Pulsed-Field Gel Electrophoresis and Comparison with That by Bacteriophage Typing. J.Clin. Microbiol. 34:959-961.

[62] Núñez Gaona O. (2004) Producción de invertasa por Aspergillus niger en fermentación en medio sólido. Tesis maestria en biotecnología. UAM-Iztapalapa, México.

[63] Servin R. L. (2006) Metalurgia de minerales no metálicos, zeolitas. http://www.monografias.com/trabajos/zeolitas/zeolitas.htm. Consulta: Abril 2012.

[64] Aguayo, S.S. y Mejía, Z. F. A. (2006) Adsorción de arsénico en zeolitas naturales pretratadas. Memorias del XVl Congreso Internacional de Metalurgia Extractiva. Saltillo, Coahuila. 303-310. 